\title{
Fiscal consolidation in developed and emerging economies
}

Consolidação fiscal em economias desenvolvidas e emergentes

\author{
Paulo André Camuri \\ Universidade Federal de Minas Gerais \\ Frederico G. Jayme Jr. \\ Universidade Federal de Minas Gerais \\ Ana Maria Hermeto \\ Universidade Federal de Minas Gerais
}

\section{Abstract}

The debate regarding fiscal policy has given support to the formulation of an economic policy based on control of indebtedness and in persecution of public savings, acting as important support for the economic growth. This paper presents evidence that counter acts this theory of expansionary austerity. A set of panel data regressions is estimated - through Driscoll $\&$ Kraay's, FGLS, panel corrected standard errors, and SUR estimators and the causality test approach proposed by Kónya (2006) - in search of robust inference related to the main determinants that encompasses the fiscal framework. Our conclusion is that the empirical evidence - using a set of 20 developed economies and other of 24 emerging economies - suggests that identical economic policies for different countries might conduce to results that are opposite to the desired outcome. Notwithstanding the adverse effects associated to explosive debt path, the search for "fiscal space" should be determined essentially by a pro-growth agenda. This is particularly important for the emerging economies facing the transition path challenges.

\section{Keywords}

fiscal austerity; economic growth; correlation; Granger causality; panel timeseries; seemingly unrelated regression (SUR).

JEL Codes E6; H62; H63.

\section{Resumo}

Este trabalho tem por objetivo desmitificar a visão dominante na literatura que atribui ganhos de crescimento às politicas de austeridade fiscal. Recorre-se a um conjunto de estimações de painel longo - por meio dos estimadores FGLS, de Driscoll \& Kraay, com erros-padrão em painéis corrigidos, SUR e do Teste de Kónya (2006) - na busca de inferências robustas acerca das principais causalidades que envolvem a problemática fiscal. Nossa conclusão é que em exercícios simultâneos a dois conjuntos de países - 24 economias emergentes e 20 desenvolvidas - as evidências empiricas dão suporte a conclusões bastante distintas entre eles, sugerindo que políticas econômicas idênticas para os paises, além de inadequadas, podem conduzir a resultados opostos aos desejados. Sem ignorar os efeitos adversos associados a trajetórias explosivas de endividamento, nosso trabalho defende que a busca por 'espaço fiscal' seja determinada essencialmente por uma agenda pró-crescimento particularmente nas economias emergentes confrontadas com os desafios de infraestruturas associados ao 'caminho de transiçãa'.

\section{Palavras-chave}

austeridade fiscal; crescimento econômico; correlação; causalidade de Granger; painel não estacionário; regressões aparentemente não correlacionadas (SUR).

Códigos JEL E6; H62; H63. 


\section{Introduction}

The debate regarding fiscal policy has been focused so far on evidence of the relationship between debt and economic growth. This has given support to the formulation of an economic policy based on control of indebtedness and in persecution of public savings, acting as important support for the economic growth.

Carmen Reinhart and Kenneth Rogoff support this argument and their papers have had a decisive impact. In the context of the international economic crisis, Akerlof et al. (2014) point out the costs of the existence of multiple equilibrium and the need of countries to seek even more conservative levels (comparatively to that suggested in a context without crisis) of indebtedness when it comes to the contingent obligations in a period of crisis.

This paper presents evidence that counteracts the traditional view of fiscal policy, known in the literature as a theory of expansionary austerity. In this regard, it is aligned to several works that point to contractionary effects (expansionary) - measured in terms of reduction (expansion) of the growth rate of the GDP - due to fiscal contractions (expansions). Although this literature, in general, analyzes the impacts on the product of reductions (expansion) of public expenses and/or increase (reduction) of the taxation, this paper used primary balances of the governments. The argument presented herein is that in simultaneous results to two different groups (developed and emerging countries), the empirical evidence supports quite different conclusions, suggesting that no general fiscal policy is able to produce similar results in all countries.

Different approaches have been used for identifying the relationship between public indebtedness (and, as a consequence, primary balance of the government) and economic growth. Only recently has the data availability enabled analyzing which perspectives are significant in cross section, and in time series. Therefore, the studies on the subject are generally restricted to a few countries and/or to very short periods. Similar studies, with countries and/or periods slightly different, lead to results sometimes very different. This literature, in general, uses time and panel (short) series. While the first framework has the advantage to treat and control the typical effects of long periods, it lacks the capacity to consider the contemporaneous effects of the 'rest of the world' in the country considered. In turn, the second framework covers shocks among countries, but addresses 
inadequately the effects of time. After all, it is, in practice, based on micro foundations, instead of macroeconomic shortcuts in their framework. ${ }^{1}$

This paper contributes with empirical literature about the relationship between primary balance and performance of the economic activity in three basic aspects. First, it focuses on causal relationships instead of correlation only, between a primary balance and economic growth. Sometimes, although such a relationship is presented, it is also less explored in the empirical literature. Moreover, the possibility of bidirectional causality is considered, exposing its liquid effect; secondly, the causality tests used herein are based on specifications that consider explicitly the premise cross-section between the countries. Although this is essential nor the Estimator Generalized Method of Moments (GMM), neither the obtained from Hurlin's approach (2008), which is more commonly used in the literature that tests causality, consider the fact that a shock in a country can affect another country, particularly in the same group whose characteristics are similar, as well as the contagious channel sometimes is clear. ${ }^{2}$ Third, this paper is the result of a simultaneously transversal and temporal panel (Time Series Cross Section Date, TSCD ${ }^{3}$.

\section{Fiscal policy}

A widespread part of the economic literature that addresses the fiscal policy and the public debt is, in general, marked by the perception that from

1 Only recently, the works which objects of study are macroeconomic, have been progressively stricter in such econometric aspects in data treatment. Until recently, as EBERHARDT (2011) states, the macroeconomics studies have used exclusively microeconomic econometric instruments, in reference to the indiscriminate use of short panels. Accordingly, they restrict the time treatment to studies of time series. The methodology of the short panel, particularly the Generalized Method of Moments (GMM), simplifies the treatment of the information related to the time cut. After all, through calculation of averages, it transforms, for instance, information of 5 time points into just one. Although this has the advantage of incorporating more information in the studies restricted to few time points no, the typical troubles of data in time series are ignored.

2 Besides these macroeconomic links, the presence of a cross-section premise in the estimates in the panel would be associated with the countries that are subject to similar institutional aspects, as would be the case of the economies signatory to the International Monetary Fund or the free trade areas, for instance. Lastly, the cross-section premise would express the effects of important local spillovers between regions and between countries.

3 Also known as Panel Time-Series or Nonstationary Panel Econometrics. For more details, see Beck, 2006. 
a certain level, the debt presents a negative impact on the economic performance of the debtor's countries. Historically, this view has appeared in the literature under different approaches: "debt overhang" (Krugman, 1988), "debt intolerance" (Reinhart; Rogoff; Savastano, 2003), "debt sustainability" (Hamilton; Flavin, 1986) and "threshold" (Reinhart; Rogoff, 2009, 2010a, 2010b, 2010c, 2013).

The relationship between public indebtedness and economic growth has indeed dominated this literature through the existence of a negative correlation between public indebtedness and economic growth. An important reference about the subject is the survey performed by Panizza and Presbitero (2013). This survey states that works focused on advanced economies have found robust results on the negative correlation between public indebtedness and economic growth, even controlling for correlated variables. Nevertheless, the authors have not found in the literature strong evidence around the existence of a causal relationship that stems from variables of indebtedness towards variables of economic performance. This discussion therefore remains open and giving rise to different guidance of economic policy.

The existence of a negative correlation between the variables mentioned could indicate that it is a smaller economic growth that deteriorates the indebtedness indicators, instead of the common belief that indebtedness leads to lower economic growth. Besides, the relationship between such variables may show the existence of a third variable that affects, simultaneously, public indebtedness and economic growth.

Since 2003, Carmem Reinhart and Keneth Rogoff have published several papers where they show the existence of a negative correlation between indebtedness and economic growth, predominantly for countries with a high level of indebtedness, above $90 \%$ of the GDP for advanced economies and above $60 \%$ of the GDP for emerging economies. It is, however, important to notice that, although the influence of Reinhart and Rogoff in the discussion about economic policy has focused particularly on the issue of the threshold, their conclusions start from the assumption of a causal link, exclusively (and/or dominantly) related to the debt towards economic growth, which is not supported by the econometric evidence utilized.

In an effort to clarify this matter, Panizza and Presbitero (2012b) suggested a new instrumental variable 4 for debt - which can capture the derived 
effects of the interaction between the debt expressed in foreign currency and the volatility of the exchange rate. Indeed, when the last variable is included, Panizza and Presbitero (2012b) reject the hypothesis of a causality link between indebtedness and growth in the countries of the OECD.

Other important references are Irons and Bivens (2010), Pattillo, Poirson and Ricci (2004) and Easterly (2001). While the former have found evidence that causality occurs from economic growth to debt, the latter use the same method as Rigobon $(2002)^{5}$ to test not only the impact of debt in economic growth, but also the contrary, thus controlling for reverse causality. The interaction between such variable is said to be significant in the two meanings. Similarly, for Easterly (2001), slowing/falls in economic activity - through its developments their repercussions in the future public revenues - tend to worsen the indicators of indebtedness of the countries, hindering the fulfillment of their debts. Moreover, the author highlights that such contamination is more severe and prolonged in heavily indebted poor countries (HIPCs).

The discussion on the effectiveness, or even the need, of austerity policies and the control of the public indebtedness reflects the difference in theoretical approaches about the channels of debt transmission. ${ }^{6}$ These, in turn, derive from a compatibility between the amount of the public debt and the intertemporal budget constraint of the government that will be satisfied whenever the primary surplus (as proportion of the GDP) is at least equal to:

$$
\left[\left(\frac{1+g}{r-g}\right) b\right]
$$

where, $g$ = growth rate of the real GDP;

$r=$ real interest rate;

$b=$ share of the public debt with respect to the GDP;

5 The method of Rigobon (2002) enables an estimate of models of simultaneous equations in the presence of heteroscedasticity in the series. Due to the absence of good instruments in such series, the identification by method of instrument variable is not possible.

6 Taylor, Proaño, Carvalho and Barbosa (2012) show a detailed analysis of these possible transmission channels, focusing especially on different causalities between the deficit/product and the debt/product ratios, suggesting that, in the North-American case, the increase of the deficit generates positive results in the product, even when the possible adverse effects in the interest rate are considered. 
The transmissions can occur: i) via a crowding out effect of the government expenses on the consumption and/or private investments; ii) via Keynesian multiplier; iii) through the effects of the public deficit in the current account of the balance of payments in a certain country; and also iv) through the Ricardian Equivalence.

The first group of studies brings the traditional view on the subject, which is contrary to expanding the share of the government expenses. The argument for it is that, by expanding its expenses, the government would compete with the private sector, only leading to an increase of its relative participation in the product, without in fact expanding it in the long term.

Alternatively, the Keynesian theory of income and production provides that changes in the government expenses affect, via multiplier, the effective demand, the employment and the product in the short term, eventually affecting the economic growth in the long term via investment. ${ }^{7}$ In the Keynesian framework, the adoption of austerity fiscal policies can thus result in effects opposed to the desired. In other words, it results in a contraction/slowdown of the economic activity and expansion of the relative participation of the public debt in the GDP. Evidently, this condition depends on idle capacity and the financial conditions of the economy. This view confirms the typical countercyclical Keynesian policy.

A third group suggests the existence of "twin deficits", which happen when countries with fiscal deficits would also present deficits in the checking account. ${ }^{8}$

Lastly, a fourth approach about the relationships between the fiscal balance and economic activity is related to the Ricardian Equivalence. As formalized by Barro (1974), such principle is based on the idea that the government cannot influence the demand in the long-term, once the bond issues that would finance the expansion of the governmental demand would be realized by private agents as a change, only temporary (current) in their incomes, without any impact on their permanent income. This would occur because the private agents, aware of the issuance of bonds, would provide for a future expansion of the levies to be charged by the government.

7 For details of the concepts of uncertainty and preference by liquidity, see Keynes (1996); for the horizontal, vertical and post Keynesian currents, see De Paula (1996); for the Kaleckian principle of increasing risk, see Kalecki (1954), and for the model of financial fragility, see Minsky (1982).

8 See, Vamvoukas (1999); Rosensweig and Tallman (1993); Feldstein (1992) and Resendo (2009). 
The conventional view, either in the Barro-Ricardo version or in the crowding-out, one disqualifies any attempt by the government to directly influence the aggregate demand, as there is no effect on the product in the long-term. Other papers, however, suggest that the net long term effect of the government intervention could be worse, or negative as they lead the product declines. Those papers focus on market reaction (vigilant bonds) to the risk of default of the public debt and as the investors' confidence reacts to the fiscal evolution. The idea is that, in the event of a need for new emissions and the aversion to the risk by the bond vigilants, there is a trend to lower the price of the bonds (therefore increasing the interest rate paid by them) either in the primary or the secondary markets. The results would be as negative in the real economy - through adverse effect in the decisions of private investment very sensitive to the interest rates - as in the financial market - via smaller attractiveness of the bonds, which can also result in a scenario of crisis of the sovereign debt.

Such an approach is thus in line with the expansionist pro-austerity argument by Alesina and Ardgna $(1998,2010)$ that provides a net increase in the aggregate demand, via income effect, arising from their belief regarding the capacity of the fiscal consolidation to avoid future situations of default and the increase of the taxation by government. The smaller probability of default could lead to a drop of the interest rate (and, therefore, valuations of assets) resulting in a boom of consumption and investment. The positive effects in the aggregate demand would overlap the initial negative effect from fiscal consolidation.

\section{Material and methods}

The database in this paper was built using different sources, yearly, from 1948 to 2012. It covers 33 economies - 20 of them developed and 13 emerging - with data available from primary result, among the 44 economies that were studied by Reinhart and Rogoff (2010b and 2013). ${ }^{9}$

9 Reinhart and Rogoff (2010 and 2013) address the correlation between debt range (from indicator "debt/GDP") and economic growth in 20 developed economies and 24 emerging, between 1946 and 2009. In both papers, the developed economies are: USA, United Kingdom, Sweden, Spain, Portugal, New Zealand, Netherlands, Norway, Japan, Italy, Ireland, Greece, Germany, France, Finland, Denmark, Canada, Belgium, Austria, and Australia. The 13 emerging economies of this paper are: Argentina, Bolivia, Brazil, Chile, Colombia, Costa Rica, Ghana, Philippines, South Africa, Mexico, Thailand, Turkey, and Venezuela. 
The series of the primary balance of the general government as share of the GDP basically comes from Mauro, Romeu, Binder and Zaman (2013) and is available for 20 developed economies and 13 emerging for a period between 1948 and 2011. For 2012, the data of the Monitor Fiscal /FMI (October 2014) was used. ${ }^{10}$

The "annual rate of the GDP growth" series was obtained by a time series built from GDP data from two sources widely used in the literature: the databases of Maddison (2013) and the Total Economy Database (TED) ${ }^{11}$. Although the second incorporates the first, the GDP series was assembled with Maddison data from 1947 to 2008 and from 2009 with data of the TED. Both sources have data in international dollars of 1990 from GearyKhamis and, therefore, result in real rates of variation of the GDP.

Besides these two main data sources, inflation data and interest rates also were used as control variables. The series of (variation of) inflation used was "64XZF" from IFS/FMI, which brings variation from the previous year, of the consumer price index (CPI). For the interest rate, according to the methodology used by Moreira and Rocha (2009), the interest rate of deposit (jdep) and the interest rate of discount (jdis) were merged - both available in the IFS/FMI - in a third, which received the name "jdd".

As our study refers to a broad set of countries and to a relatively long period, ignore and/or do not treat appropriately the time effects, the autocorrelations of the heterogeneity between the countries would indeed imply to underestimate the elements that determine the processes that the study seeks to understand. Thus, rather than to organize the observations by debt range ignoring the other heterogeneities and correlations between the countries, we prioritize them despite the type of indebtedness of each country.

This study performed an econometric instrumental still little explored in macroeconomic studies and particularly in the economy and fiscal policy. By exploring cross-section data and time series, this methodological framework (long panel) benefits in degrees of freedom and efficiency of

10 There is no data available in this series for the following countries that are in Reinhart and Rogoff (2010, 2013): Ecuador, El Salvador, Indonesia, Malaysia, Kenya, Uruguay, Peru, Singapore and Nigeria. The number of notes of India and Sri Lanka are not enough for the procedures performed.

11 The database of Maddison is available at http://www.ggdc.net/MADDISON/oriindex. htm ("horizontal-file_02_2010" and "vertical-file_02_2010"). The TED is available at http:// graduateinstitute.ch/home/study/academicdepartments/international-economics/md4stata/ datasets/ totecon.html. 
the estimated parameters, while minimizing collinearity between the explanatory variables. In addition, it controls the effects associated with the omission of important explanatory variables. Another advantage is that the method involves long panel heterogeneity among countries which in practice allows hypothesis testing to be performed separately for each country. By merging broadly available information and robust estimations over time and in a cross section to the different heterogeneities between and within the countries, to the autocorrelations, and to the unit root and the cross-section dependence, this exercise presents sensitive specifications to the characteristics above. It can lead to results and, ultimately, suggestions of economic policy that is significantly different from the one found when these features are ignored.

Therefore, three sets of procedures were performed: i) a set of long panel estimates with specific controls for heteroscedasticity and correlation, namely, FGLS (Parks, 1967); Driscoll and Kraay estimator (1998) from procedure proposed by Hoechle (2007); and Panel Correct Standard Error (PCSE) proposed by Beck and Katz (1995) from OLS and Prais-Winsten estimators; ii) Seemingly Unrelated Regression (SUR); and iii) Kónya Test (2006) on bidirectional causality. Previously, tests of stationarity were performed (Test of Fisher, Maddala and Wu, 1999 and Test of Pesaran, 2007), as well as cointegration (Teste of Pedroni, 1999 and Westerlund, 2007) and contemporary dependence (cross section dependence, via Pesaran, 2004) ${ }^{12}$. The purpose was to find inferences of the causalities between primary balance and GDP growth.

Although the FGLS, Driscoll and Kraay estimates (1998), and estimates with PCSE deal in different ways with the troubles of heterogeneity, such as self-correlation and contemporary correlation, they have the disadvantage of only bringing results to set of countries. Given the heterogeneity between the countries, the expectation of a dependence of the error terms and the significant variation of the primary balance in a same country over time, we used the SUR methodologies and the Kónya Test (2006) to obtain results sensitive to the dynamics that are possibly differentiated, country by country, of causality between primary balance and economic growth.

As we consider this feature a particularly important point, and because we want to infer causalities between primary balance and GDP growth 12 Bai and Kao (2006) alert that negligence of the contemporary dependence, when this exists, might make the results biased and inconsistent. 
that is eventually different among countries, we used the SUR estimator, which is more efficient compared to the estimator $\mathrm{MQO}$ in the presence of a cross-section dependence. ${ }^{13}$

Both SUR and the Kónya Test are linked to Phillips and Hansen (1990) and Phillips (1995) that propose, respectively, the Fully Modified Least Squares, FM-OLS, and the Fully Modified VAR, FM-VAR originally by Zellner (1962) on the estimator SUR. ${ }^{14}$

According to that original theory, and to a bivariate autoregressive vector of finite order such as the following presented, Konya (2006) proposes a test of Granger causality between two variables, country by country, applied specifically to data in a panel and guided by the estimator SUR ${ }^{15}$ :

$$
\begin{aligned}
& Y_{i, t}=\alpha_{1, t}+\sum_{l=1}^{m l y_{i}} \beta_{1, i, l} Y_{i, t-l}+\sum_{l=1}^{m l x_{i}} Y_{1, i, l} X_{i, t-l}+\varepsilon_{1, i, t} \\
& X_{i, t}=\alpha_{2, i}+\sum_{l=1}^{m l y_{i}} \beta_{2, i, l} Y_{i, t-l}+\sum_{l=1}^{m l x_{i}} Y_{2, i, l} X_{i, t-l}+\varepsilon_{2, i, t}
\end{aligned}
$$

where, $i=1, \ldots ., \mathrm{N}$ refers to the country;

$t=1, \ldots, \mathrm{T}$ to the year;

$l=$ lag; and

$\varepsilon_{1, i, t}$ e $\varepsilon_{2 i, t}$ are white noise and can be correlated for a certain country, but not between the countries.

Noticing that a certain country shows in (2) the same exogenous and endogenous variables, the OLS are consistent and asymptotically efficient so that the $2 \mathrm{~N}$ equations could be estimated one by one in any order. In other words, rather than $\mathrm{N}$ systems VAR as in (2), we could start from two sets of equations, one for $\mathrm{Y}$ and another for $\mathrm{X}$, where the contemporary correlation would become the single possible link between 13 In the presence of contemporary correlation (cross section dependence) the estimators MQO are no longer BLUE (best linear unbiased estimators).

14 The Estimator SUR is more efficient than OLS, in the presence of contemporary correlation, precisely to explore the additional information supplied by the panel and ignored in other procedures.

15 In the case of this study, the Konya Test was applied to analyze the possible causalities between the primary result of the government and GDP growth. Kar, Nazlioglu and Agir (2011) adopt a similar procedure to test the causalities between financial development and economic growth. 
the regressions for each country, once each equation, both systems (3) and (4), would present different exogenous and endogenous variables. Therefore, the systems lose the VAR characteristic and may start to be treated as SUR.

$$
\begin{aligned}
& Y_{2, t}=\alpha_{1,2}+\sum_{l=1}^{m l y_{1}} \beta_{1,2, l} Y_{2, t-l}+\sum_{l=1}^{m l x_{1}} \gamma_{1,2, l} X_{2, t-l}+\varepsilon_{1,2, t} \\
& Y_{N, t}=\alpha_{1, N}+\sum_{l=1}^{m l l_{1}} \beta_{1, N, l} Y_{N, t-l}+\sum_{l=1}^{m l x_{1}} \gamma_{1, N, l} X_{N, t-l}+\varepsilon_{1, N, t}
\end{aligned}
$$

and

$$
\begin{aligned}
& X_{1, t}=\alpha_{2,1}+\sum_{l=1}^{m l y_{y_{2}}} \beta_{2,1, l} Y_{1, t-l}+\sum_{l=1}^{m l x_{2}} \gamma_{2,1, l} X_{1, t-l}+\varepsilon_{2,1, t} \\
& X_{2, t}=\alpha_{2,2}+\sum_{l=1}^{m l y_{2}} \beta_{2,2, l} Y_{2, t-l}+\sum_{l=1}^{m l x_{2}} \gamma_{2,2, l} X_{2, t-l}+\varepsilon_{2,2, t} \\
& X_{N, t}=\alpha_{2, N}+\sum_{l=1}^{m l y_{2}} \beta_{2, N, l} Y_{N, t-l}+\sum_{l=1}^{m l x_{2}} \gamma_{2, N, I} X_{N, t-l}+\varepsilon_{2, N, t}
\end{aligned}
$$

This is how the hypothesis of no causality through a Wald test of restrictions can be investigated. There would be unidirectional causality from $X$ to $\mathrm{Y}$ if not all $\gamma_{1 i}$ were equal to zero in (3), but all $\beta_{2 i}$ were equal to zero in (4). There would be unidirectional causality from $\mathrm{Y}$ to $\mathrm{X}$ if all $\gamma_{1 i}$ were equal to zero in (3), but not all $\beta_{2 i}$ were equal to zero in (4). There would be bidirectional causality between X and Y if not all $\beta_{2 i}$ and not all $\gamma_{1 i}$ were equal to zero ( 3 and 4). Lastly, there would not be causality between $\mathrm{X}$ and $\mathrm{Y}$ if all $\gamma_{1 i}$ and all $\beta_{2 i}$ were equal to zero (3 and 4$)$.

\section{Evidence between primary balance and economic growth}

Tables 1 and 2 show results of estimations related to the causal relationships between the government primary balance and the GDP performance. Before making the aforementioned estimations, it was identified through panel procedures that the series of government primary balance - both for developed countries and for emerging countries - do not have a unit root. They have, instead, a cross section dependence and - at least for the set of 
developed - they are cointegrated with the series of GDP growth ${ }^{16}$.

This analysis, initially made for all the countries together, indicates that primary balances are related contemporaneously and/or a period ahead - at positive rates of GDP growth, either in emerging as in developed economies, but would be significantly greater in the emerging (see Table 1$)^{17}$. Therefore, such evidences would be aligned to the pro-austerity expansionist argument that provides a net increase in the aggregate demand, via income effect of the agents. In other words, the positive effects in the aggregate demand would overlap initial negative effect from fiscal consolidation.

Table 2 reveals, as expected, that the GDP growth positively affects to $5 \%$ significance the government's primary balance, both in the emerging and in the developed countries. One could notice that this impact seems to be significantly greater in developed countries, suggesting that these would save considerably more than emerging in periods of economic growth. These results are in accordance with Kaminsky et al. (2004), where "when it rains, it pours", suggesting that fiscal policy of the emerging countries would tend to intensify, and not to relax, the effects of the business cycles $^{18}$. Although we do not explicitly analyze the government expenses and revenues, the results of Table 2 seem to support this viewpoint.

Although given the robustness of these results, it is important to highlight that this first methodological approach ignores the presence of the cross-section contemporary dependence among countries. Therefore, they ignore the contemporaneous and crossed effects among countries related to the markets of bonds and to obtaining fiscal surplus and/or deficits. The dynamic of some countries has to be analyzed more cautiously, since it can be highly different than their group. Indeed, the SUR estimations can enable those features.

Our results through SUR estimations (Table 3) and the Kónya Test (Table 4), indeed, reveal some causalities that are significantly different from the ones presented to the set of countries. Both SUR estimations

16 The results of the tests of stationarity in panel of Fisher, Maddala and Wu (1999), of cointegration of Westerlund (2007) and Pedroni (1999), and Pesaran (2004) of cross-section dependence are in the Annexes. The test of Westerlund (2007) cannot be performed to the set of emerging countries due to the great number of "missings".

17 The Tables 1 (above) and A6 (Annexes) are different because they have, respectively, inflation and interest rate as control variable.

18 Ilzetzki, Mendonza and Végh (2013) and Ilzetzki and Végh (2008) came to similar conclusions. 
and the Kónya Test share evidences that for Austria, Belgium, Denmark, Italy, Norway and Portugal (developed), a primary surplus would cause a negative effect a period ahead (instead of positive, as pointed out in the estimations that ignore the presence of a cross-section dependence in the data) in terms of GDP growth rate ${ }^{19}$. Kónya Tests suggest evidence in this regard also for Finland, Germany, Canada, France, Netherlands, UK, USA (developed) and Turkey (emerging). These would be evidences against the expansionary austerity theory and are aligned to several papers that point out effects of slowdown or recession - measured in terms of reduction of the GDP growth rate and/or deterioration in the indicator DIV/PIB - derived from fiscal contractions, either through cuts in public expenses and/ or increase of taxation. Callegari et al. (2012), Crotty (2012), Taylor et al. (2012), and McCausland and Theodossion (2014) are important references in this line of work.

Regarding the evidences in favor of the expansionary austerity theory, the SUR procedure identifies only the case of Argentina, Bolivia, Colombia, Philippines and Venezuela (emerging) and Ireland (developed). According to the Kónya Test, this would be the case of the emerging Argentina and Thailand (emerging countries), with unidirectional causality, and Ireland, New Zealand (developed countries) as well as Venezuela and Chile (emerging countries), with bidirectional causality. Thus, despite the distinct methodology and without targeting the data in government revenues and expenses, our results (guided by series of government primary balance) indicate that, in fact, there are empirical evidences that some countries can enjoy expansionary fiscal consolidation ${ }^{20}$. This paper contributes to this literature by presenting evidence in this direction for emerging economies as well, once most of the papers refer exclusively to developed economies and/or OECD, like Giavazzi and Pagano (1990); Alesina and Ardagna (1998, 2010); McDermott and Wescott (1996); Giavazzi, Jappelli and Pagano (2000); Ardagna (2004); and Lambertini and Tavares (2005).

Considering the inverse order of causality and guided by SUR estimations, increases in the GDP would lead to improvements in the primary balance a period ahead for Australia, France, Greece, Netherlands,

19 Kónya is different from the SUR estimation due to simultaneously considering the inverse order of causality Granger.

20 Fiscal consolidation is an authority fiscal policy in long-term. 


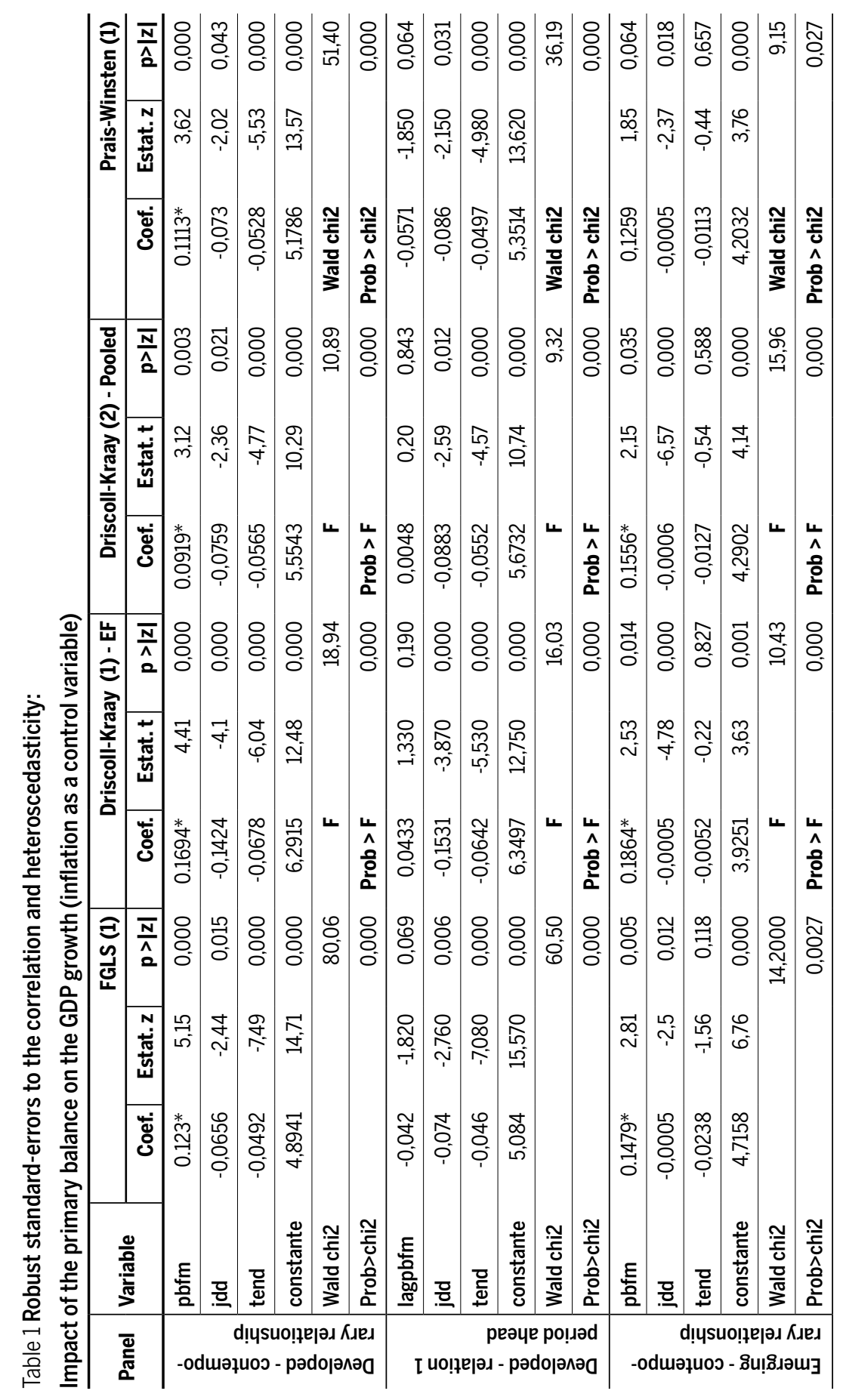




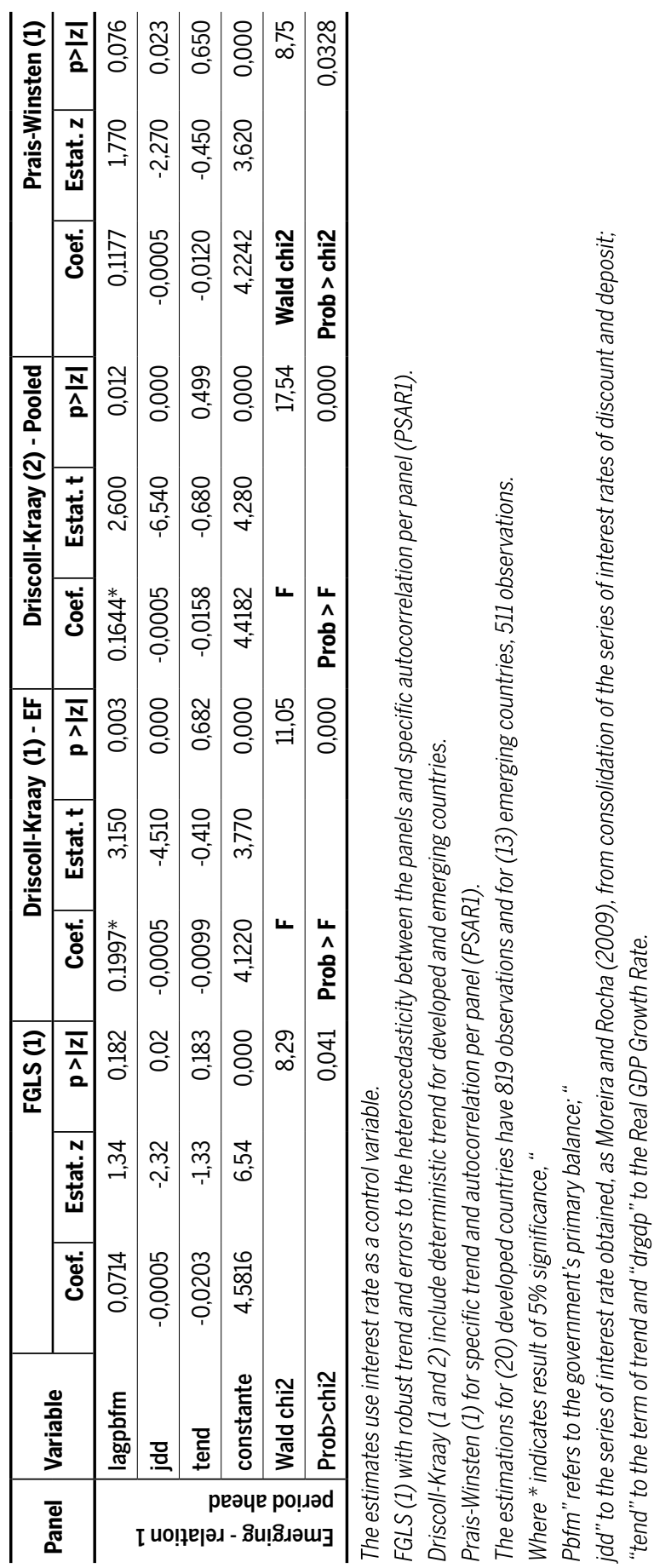




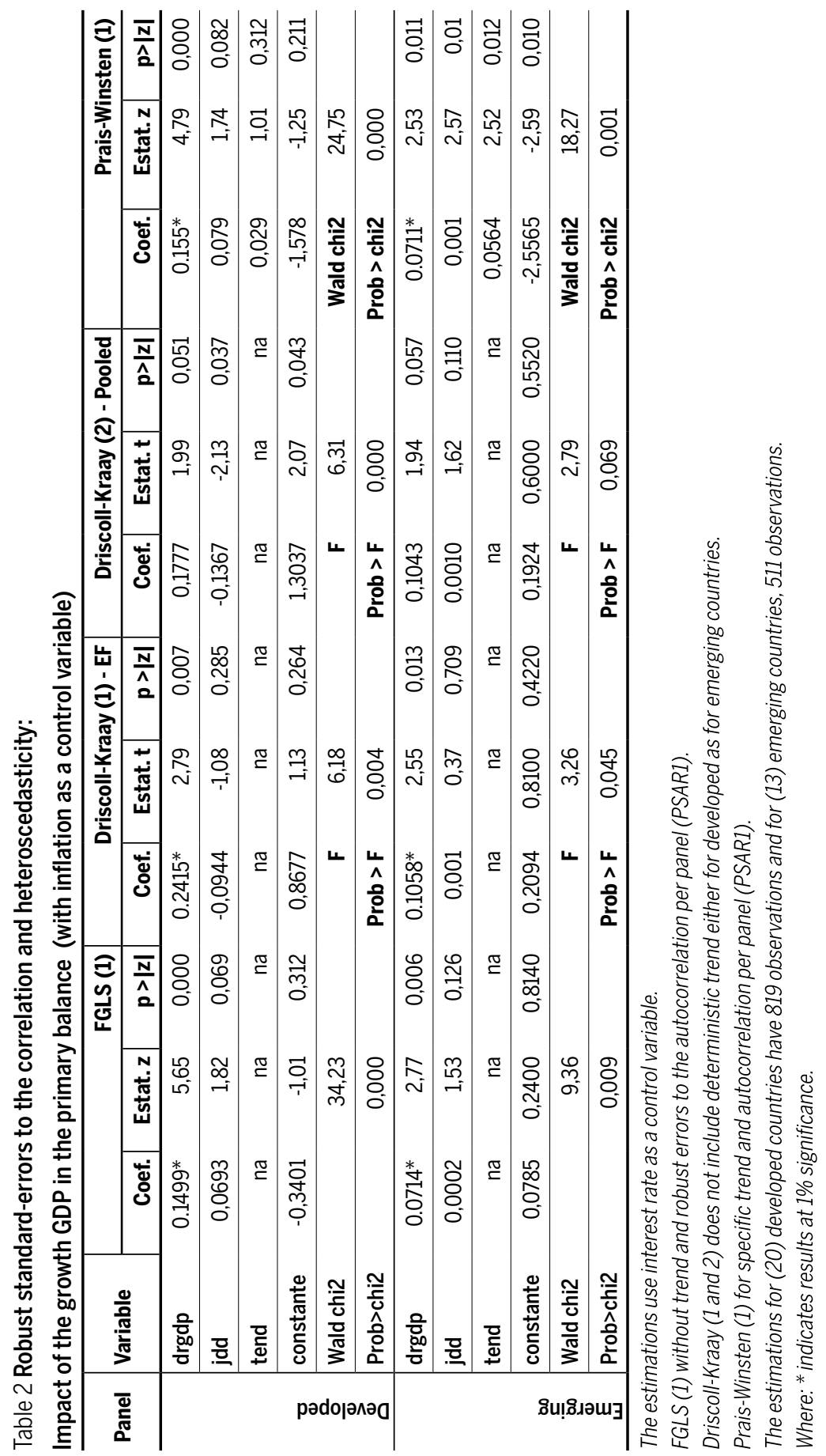


New Zealand, Sweden and England (developed countries) and Argentina, Chile and Thailand (emerging countries). The Kónya Test suggests that this positive effect would occur unidirectionally in Australia, Japan, Spain and Sweden (developed countries) and bidirectionally in the Canada, Denmark, France, Netherlands, Portugal, England, USA, Ireland and New Zealand (developed countries) and Chile (emerging country). In other words, the results suggest - contrary to the results of the estimations FGLS, Driscoll-Kraay and Prais-Winsten - that the rate of public savings tends to increase in a growth period, not exclusively in developed economies. For Italy (developed country) and Turkey, Venezuela, Colombia and Mexico (emerging countries) the evidence - according to the Kónya Test - is, in fact, that GDP growth periods would be associated with declines, a period ahead, in the primary balances. The same would happen, according to the results of the SUR estimations, in the Norway (developed country) and Brazil (emerging country), indicating that fiscal indicators in these economies would get worse, rather than improve, in economic growth periods.

Table 3 Causal relationships between primary balance and economic growth:

\section{SUR at $5 \%$ significance}

\begin{tabular}{l|c|l|l}
\hline Causality & Coef. Sign & Developed Countries & Emerging Countries \\
\hline $\begin{array}{l}\text { Lag of the } \\
\text { Pbfm for GDP }\end{array}$ & + & Ireland & $\begin{array}{l}\text { Argentina, Bolivia, Colombia, } \\
\text { Philippines and Venezuela }\end{array}$ \\
\cline { 2 - 4 } Growth $(\varphi)$ & - & $\begin{array}{l}\text { Austria, Belgium, Denmark, Italy, } \\
\text { Norway and Portugal }\end{array}$ & - \\
\hline $\begin{array}{l}\text { Lag of the } \\
\text { GDP Growth } \\
\text { for Pbfm }(\alpha)\end{array}$ & + & $\begin{array}{l}\text { Australia, France, Greece, Nether- } \\
\text { lands, New Zealand, Sweden and } \\
\text { England }\end{array}$ & Argentina, Chile and Thailand \\
\cline { 2 - 4 } & - & Norway & Brazil \\
\hline
\end{tabular}

Causality Test of the Lag of the Primary Balance towards GDP Growth:

$d r g d p=+\varphi$ Lagpbfm $(+\beta$ Lag jdd $)+C$, where $C=$ constant .

Causality Test of the Lag of GDP Growth towards Primary Balance:

$\operatorname{drg} d p=+\varphi$ Lagpbfm $(+\beta$ Lag jdd $)+C$.

Data not available for estimations for Ecuador, El Salvador, India, Indonesia, Kenya, Malaysia, Nigeria, Peru, Singapore, Sri Lanka or Uruguay (emerging countries).

Data is not sufficient to the first estimation for: Germany, Netherlands, New Zealand, Spain, Sweden and USA; and to the second estimation for: Austria, Canada, Finland, Germany, Netherlands, Italy, Japan, Portugal and USA (developed countries).

Result at 5\% significance. 
Table 4 Causal relationships between primary balance and economic growth:

Kónya Test at $5 \%$ significance

\begin{tabular}{|c|c|c|c|c|}
\hline Causality & \multicolumn{2}{|c|}{ Coef. Sign } & Developed Countries & Emerging Countries \\
\hline \multirow{2}{*}{$\begin{array}{l}\text { Lag of the pri- } \\
\text { mary result for } \\
\text { GDP growth }(\varphi)\end{array}$} & \multicolumn{2}{|c|}{+} & - & Argentina and Thailand \\
\hline & \multicolumn{2}{|c|}{-} & $\begin{array}{l}\text { Austria, Belgium, Finland, } \\
\text { Germany and Norway }\end{array}$ & - \\
\hline \multirow{3}{*}{$\begin{array}{l}\text { Lag of the GDP } \\
\text { growth for pri- } \\
\text { mary result }(\beta)\end{array}$} & \multicolumn{2}{|c|}{+} & $\begin{array}{l}\text { Australia, Japan, } \\
\text { Spain and Sweden }\end{array}$ & - \\
\hline & \multicolumn{2}{|c|}{-} & - & Colombia and Mexico \\
\hline & $\varphi$ & $\beta$ & & \\
\hline \multirow{4}{*}{ Bidirectional } & + & - & - & Venezuela \\
\hline & - & + & $\begin{array}{l}\text { Canada, Denmark, France, } \\
\text { Netherlands, Portugal, England } \\
\text { and USA }\end{array}$ & - \\
\hline & + & + & Ireland and New Zealand & Chile \\
\hline & - & - & Italy & Turkey \\
\hline None & \multicolumn{2}{|c|}{ NA } & - & $\begin{array}{l}\text { Bolivia, Costa Rica, Ghana, } \\
\text { Philippines and South Africa }\end{array}$ \\
\hline
\end{tabular}

Causality Test of the Primary Balance in direction to the GDP Growth: $Y_{N, t}=\alpha+\Sigma \beta Y_{t-1}+\Sigma \phi X_{t-1}+\varepsilon$ and the GDP Growth in direction to the Primary Balance: $X_{N, t}=\alpha+\Sigma \beta Y_{t-1}+\Sigma \phi X_{t-1}+\varepsilon$

Data not available in estimations for Ecuador, El Salvador, India, Indonesia, Kenya, Malaysia, Nigeria, Peru, Singapore, Sri Lanka and Uruguay (emerging countries).

Data is not sufficient for: Austria, Canada, Finland, Greece, New Zealand, Norway, Sweden and England (developed countries) and Brazil (emerging country).

Result at 5\% significance

\section{Conclusions}

A general conclusion of this paper is that some countries would not enjoy expansionary fiscal consolidation. In this regard, our results counteract the arguments that the increase in the public savings and declines in the rate Debt/GDP would be sine-qua-non conditions to the economic growth. Moreover, they suggest that increased fiscal and primary surplus would lead to even more contractionary effects in the emerging economies if compared to developed ones. The empirical results suggest that it is not possible to generalize empirically the relationship between economic growth and public indebtedness. Indeed, if theoretically there is no agree- 
ment regarding this discussion, we show that empirically there is also no room for a consensus.

As far as we know, the empirical results we show in this paper is new in the literature regarding indebtedness and fiscal policy both in emerging and developed economies. Indeed, we benefit simultaneously the broad (and only recent) cross-section and timely database, with significant gain of information comparatively to the methodologies of panel and time series usually used. The results are robust in different ways to generate the data: heteroscedasticity inside and between the countries, autocorrelation, unit root and cross-section dependence. Besides, it required the substantial volume of estimations, tests and specifications presented herein.

For country groups, the FGLS estimations, from Driscoll \& Kraay, and with standard-errors in panels adjusted corroborate in the two groups of countries studied herein, the dominant thesis of expansionist fiscal austerity (Alesina; Ardgna, 1998, 2010) and that the governments of emerging economies would have greater difficulty to save in growth periods. "When it rains, it pours" as Kaminsky et al. (2004), comparatively to the developed countries. The methodology employed, by enabling comparisons between developed and emerging countries, allows to weigh and even question the conclusions, such as those of economic policy, formulated from these initial results (per group), and correspondingly, from dominant literature that shares this vision.

Moreover, when we turn to a modeling that considers the contemporary dependence (cross-section) among the countries, the different heterogeneities between them over time, as well as all possible directions of causality, our results reveal that certain countries may present dynamics significantly distinct from those attributed to the groups of which they are part. The results both for the SUR as the Kónya Test share evidence that for Austria, Belgium, Denmark, Italy, Norway and Portugal (developed countries), of the growth of the primary surplus would harm economic growth one period ahead. The estimations of the Kónya Test suggest evidence in this regard also to Finland, Germany, Canada, France, Netherlands, UK, USA (developed) and Turkey (emerging).

Therefore, the SUR estimations and of the Kónya Test suggest, contrary to the traditional view of expansionary fiscal consolidation, - that declines of the primary balance would be associated, for a significant group of countries, to increases a period ahead (instead of declines) in the growth rates. 
In this regard, this paper pays attention to the risks of adopting Debt/ GDP goals as a single and unequivocal indicator of the fiscal condition of the countries. In this context, the belief in the expansionary fiscal austerity often has opposite effects and requires increasing fiscal efforts without visible success. Besides, as Ostry, Loungani and Furceri (2016) highlight, fiscal austerity is associated with increased income inequality.

Future research could investigate the effects of the fiscal consolidation on unemployment and income distribution in the fashion of McCausland and Theodossion (2014). Such analyses have been evaluating so far, but econometric evidence used herein can contribute to new and important insights of economic theory and policy.

\section{References}

AKERLOF, G. A.; BLANCHARD, O. J.; ROMER, D.; STIGLITZ, J. E. (Eds.) What have we learned? Macroeconomic Policy after the Crisis. MIT Press, 2014.

ALESINA, A.; ARDAGNA, S. Tales of fiscal adjustment. Economic Policy, n.13, p.487-545, 1998.

ARDAGNA, S. Large changes in Fiscal Policy: Taxes versus Spending. In: NATIONAL BUREAU OF ECONOMIC RESEARCH. Tax Policy and the Economy. v.24, NBER Chapters, p.35-68, 2010.

ARDAGNA, S. Fiscal stabilizations: When do they work and why? European Economic Review, n.48 (October), p.1047-74, 2004.

BAI, J.; KAO, C. On the estimation and inference of a panel co-integration method with cross-sectional dependence. In: BALTAGI, B. H. (Ed.). Panel data econometrics: theoretical contributions and empirical applications. Elsevier Science \& Technology, 2006.

BARRO, R. J. Are government bonds net wealth? Journal of Political Economy, v.82, n.6, p.10951117, 1974.

BECK, N. Time series cross section methods. New York University, NY, USA. Draft of June 5, 2006.

BECK, N.; KATZ, J. What to do (and not to do) with Time-Series Cross-Section Data. The American Political Science Review. v.89, n.3 (Sep.), p. 634-647, 1995.

CALLEGARI, G.; MELINA, G.; e BAITINI, N. Successful austerity in the United States, Europe and Japan. IMF Working Papers 12/190, International Monetary Fund, July, 2012.

CROTTY, J. The great austerity war: what caused the US deficit crisis and who should pay to it? Cambridge Journal of Economics, n. 36, p.79-104, 2012.

DE PAULA, L. F. R. Liquidez e zeragem automática: crítica da crítica. Est. Econ. São Paulo, v.26, n.3, p. 411-439, 1996.

DRISCOLL, J. C.; KRAAY, A. C. Consistent covariance matrix estimation with spatially dependent panel data. Review of Economics and Statistics, n.80, p.549-560, 1998. 
EASTERLY, W. R. Growth implosions and debt explosions: Do growth slowdowns cause public debt crises? Contributions to Macroeconomics. WB. v.1, issue 1. Article 1, 2001.

EBERHARDT, M. Panel time-series modeling: New tools for analyzing xt data. In: UK Stata Users Group meeting. Cass Business School, London. $16^{\text {th }}$ September, 2011. Available at: $<$ http://sites.google.com/site/medevecon>.

FELDSTEIN, M. The budget and trade deficits aren't really twins. NBER Working Paper $n$. 3966. Cambridge, janeiro, 1992.

FUNDO MONETÁRIO INTERNACIONAL - FMI. Fiscal Monitor: Back to work. How fiscal policy can help. Washington, DC, 2014.

GIAVAZZI, F; JAPELLI, T.; PAGANO, M. Searching for non-linear effects of fiscal policy: Evidence from industrial and developing countries. European Economic Review v.44, n.7, p.1259-89, 2000.

GIAVAZZI, F; PAGANO, M. Can severe fiscal contractions be expansionary? Tales of two small European countries. NBER Macroeconomics Annual, p.95-122, 1990.

HERNDON, T; ASH, M.; POLLIN, R. Does high public debt consistently stifle economic growth? A critique of Reinhart and Rogoff. Cambridge Journal of Economics, n.1 of 23. December 24, 2013.

HAMILTON, J. D.; FLAVIN, M. A. On the limitations of government borrowing: a framework for empirical testing. The American Economic Review, v.76, n.4, p.808-819, 1986.

HOECHLE, D. Robust standard errors for panel regressions with cross-sectional dependence. Basel, Switzerland: Department of Finance. University of Basel, 2007.

HURLIN, C. Testing for Granger Causality in heterogeneous panels. Mimeo. Department of Economics: University of Orleans, 2008.

ILZETZKI, E.; MENDOZA, H. G.; VÉGH, C. A. How big (small?) are fiscal multipliers? Journal of Monetary Economics, n.60, p.239-254, 2013.

ILZETZKI, E.; VÉGH, C.A. Procyclical Fiscal Policy in Developing Countries: Truth or Fiction? NBER Working Paper 14191, 2008.

IRONS, J.; BIVENS, J. Government debt and economic growth: Overreaching claims fof debt "Threshold" Suffer from theorical and empirical Flaws. Economic Policy Institute (EPI) Briefing Paper, n. 271. 26, July, 2010.

KAMINSKY, G.; REINHART, C. M.; VÉGH, C. A. When it rains it pours: pro-cyclical capital flows and macroeconomic policies. In: GERTLER, M.; ROGOFF, K. S. (Eds.). NBER Macroeconomics Annual 2004, National Bureau of Economic Research, p.11-82, 2004.

KAR, M.; NAZLIOGLU, S.; AGIR, H. Financial development and economic growth nexus in the MENA countries: Bootstrap panel granger causality analysis. Economic Modelling, n.28, p.685-693, 2011.

KEYNES, J. M. A teoria geral do emprego, do juro e da moeda. São Paulo: Nova Cultural, 1996.

KÓNYA, L. Exports and growth: Granger causality analysis on OECD countries with a panel data approach. Economic Modelling, Elsevier, v. 23, n.6, p.978-992, December, 2006.

KRUGMAN, P. Financing versus forgiving a debt overhang. Working Paper n. 2486, 1988.

LAMBERTINI, L.; TAVARES, J. A. Exchange rates and fiscal adjustments: Evidence from the 
OECD and implications for the EMU. Contributions to Macroeconomics, v.5, n.1, art. 11, 2005. Available at: <http://www.bepress.com/bejm/contributions/vol5/iss1/art11>.

MADDALA, G.; WU, S. A comparative study of Unit Root Tests and a New Simple Test. Oxford Bulletin of Economics and Statistics, v.61, n.1, p.631-652, 1999.

MAURO, P.; ROMEU, R.; BINDER, A; ZAMAN, A. A modern history of fiscal prudence and profligacy. International Monetary Fund. January, 2013.

McCAUSLAND, W. D; THEODOSSIOU, I. The consequences of fiscal stimulus on public debt: A historical perspective. Department of Economics and Centre for European Labour Market Research. Prime, October, 2014.

McDERMOT, J.; WESCOTT, R. An empirical analysis of fiscal adjustments. IMF Staff Papers 43 no. 4, p.723-53, 1996.

MINSKY, H. Can it happen again? Essays on instability \& finance. Armonk, New York: Sharpe, 1982, 301p.

MOREIRA, A.; ROCHA, K. A política fiscal e as taxas de juros domésticas nos países emergentes. Texto para Discussão. IPEA, Novembro, 2009.

OSTRY, J. D; ATISH, R. G.; ESPINOSA, R. When should public debt be reduced? IMF Staff Discussion Note 15/10. Washington: International Monetary Fund, 2015.

OSTRY, J.D; LONGANI, P..; FURCERI, D. Neoliberalism: Oversold? Finance and Development, June, 2016.

PANIZZA, U.; PRESBITERO, A. F. Public debt and economic growth in advanced economies: A survey. Swiss Journal of Economics and Statistics, forthcoming, 2013.

PANIZZA, U.; PRESBITERO, A. F. Is high public debt harmful for economic growth? VoxEU. org, 22, April, 2012a.

PANIZZA, U.; PRESBITERO, A. F. Public debt and economic growth: Is there a causal effect? MoFiR Working Paper n. 65. Ancona, Italy: Money and Finance Research Group. 2 April, $2012 b$.

PARKS, R. Efficient estimation of a system of regression equations when disturbances are both serially and contemporaneously correlated. Journal of the American Statistical Association, n.62, p.500-509, 1967.

PATILLO, C.; POIRSON, H.; RICCI, L. What are the channels through which external debt affects the growth. IMF Working Paper. n. 15, January, 2004.

PEDRONI, P. Critical values for co-integrating tests in heterogeneous panels with multiple regressors. Oxford Bulletin of Economics and Statistics, v.61, n.1, p.653- 670, 1999.

PESARAN, M. A simple panel unit root test in the presence of cross section dependence. Journal of Applied Econometrics, v.22, n.2, p.265-312, 2007.

PESARAN, M. General Diagnostic Tests for Cross Section Dependence in Panels. Cambridge Working Papers in Economics No. 0435. Faculty of Economics, University of Cambridge, 2004.

PHILLIPS, P. C. B. Fully modified least squares and vector auto-regression. Working Paper $n$. 905. Cowles Foundation for Research in Economics. Yale University, 1995.

PHILLIPS, P. C. B.; HANSEN, B. E. Statistical inference in instrumental variables regressions with I (1) Processes. Review of Economic Studies, v.57, p.99-125, 1990. 
REINHART, C. M.; ROGOFF, K. S. Reinhart-Rogoff Response to Critique. The Wall Street Journal, 16 April, 2013.

REINHART, C. M.; ROGOFF, K. S. Debt and Growth Revisited. VoxEU.org, v.11, August, 2010a.

REINHART, C. M.; ROGOFF, K. S. Growth in a Time of Debt. National Bureau of Economic Research WP 15639. Cambridge, MA. Janeiro, 2010 b.

REINHART, C. M.; ROGOFF, K. S. Growth in a time of debt. American Economic Review: Papers and Proceedings, v.100, n.2, p.573-578, May, 2010c.

REINHART, C. M.; ROGOFF, K. S. This Time is Different: Eight Centuries of Financial Folly. Princeton, NJ: Princeton University Press. October, 2009.

REINHART, C. M.; ROGOFF, K. S.; SAVASTANO, M. A. Debt intolerance. Booking Papers on Economic Activity, Spring, p.1-74. August, 2003.

RESENDE, M. F. C. Déficits gêmeos e poupança nacional: abordagem teórica. Rev. Econ. Polit. [online], v.29, n.1, p.24-42, 2009.

RIGOBON, R. Identification through heteroskedasticity. Sloan School of Management, MIT and NBER. June, 2002.

ROSENSWEIG, J. A.; TALLMAN, E. W. Fiscal policy and trade adjustment: are the deficits really twins? Economic Inquiry, v. 31, October, 1993.

TAYLOR, L.; PROAÑO, C. R.; CARVALHO, L.; BARBOSA, N. Fiscal deficits, economic growth and government debt in the USA. Cambridge Journal of Economics, v.36, p.189-204, 2012 .

VAMVOUKAS, G. A. The twin deficits phenomenon: evidence from Greece. Applied Economics, v.31, 1999.

WESTERLUND, J. Estimating co-integrated panels with common factors and the forward rate unbiasedness hypothesis. Journal of Financial Econometrics, v.5, n.3, p.491-522, 2007.

WOOLDRIDGE, J. Econometric Analysis of Cross Section and Panel Data. Cambridge, MA: MIT Press, 2002.

ZELLNER, A. An efficient method of estimating seemingly unrelated regressions and tests of aggregation bias. Journal of the American Statistical Association, v.57, p.348-368, 1962.

\section{About the authors}

Paulo André Camuri - pcamuri@hotmail.com

Doutor em Economia pelo CEDEPLAR - Universidade Federal de Minas Gerais.

Frederico G. JaymeJr.-gonzaga@cedeplar.ufmg.br

Professor do Cedeplar- Universidade Federal de Minas Gerais.

AnaMariaHermeto - ahermeto@cedeplar.ufmg.br

Professora do Cedeplar- Universidade Federal de Minas Gerais.

\section{About the article}

Submission received on May 11, 2016. Approved for publication on June 13, 2016. 


\section{Annexes}

Table A1 Tests of stationarity in panel:

Primary balance of the government test of Fisher, Maddala and Wu (1999)

\begin{tabular}{l|rr|r|r|r|r|r|r}
\hline \multirow{3}{*}{ Lags } & \multicolumn{1}{|r}{ Developed } & \multicolumn{4}{r}{ Emerging } \\
\cline { 2 - 9 } & without trend & with trend & without trend & \multicolumn{2}{|r}{ with trend } \\
\cline { 2 - 9 } & $\mathbf{p b}$ & p-value & $\mathbf{p b}$ & $\mathbf{p}$-value & $\mathbf{p b}$ & $\mathbf{p}$-value & $\mathbf{p b}$ & $\mathbf{p}$-value \\
\hline $\mathbf{0}$ & 130.428 & 0.000 & 91.458 & 0.000 & 110.475 & 0.000 & 82.377 & 0.000 \\
\hline $\mathbf{1}$ & 160.594 & 0.000 & 118.839 & 0.000 & 104.057 & 0.000 & 75.595 & 0.000 \\
\hline $\mathbf{2}$ & 149.461 & 0.000 & 109.094 & 0.000 & 75.504 & 0.000 & 53.969 & 0.002 \\
\hline $\mathbf{3}$ & 111.374 & 0.000 & 77.057 & 0.000 & 62.779 & 0.000 & 40.537 & 0.059 \\
\hline
\end{tabular}

For Maddala and Wu (1999) the statistic chi-square associated with the Test of Fisher and the p-value is shown. The null hypothesis is that the series are non-stationary.

The deterministic elements and the lags are related to the Dickey Fuller regressions.

The "multipurt" routine was used from Markus Eberhardt, covering the "xtfisher" and "pescadf" routines and written, respectively, by Scott Merryman and Piotr Lewandowski.

Results at $5 \%$ significance.

Table A2 Tests of stationarity in panel:

Primary balance of the government test of Pesaran (2007)

\begin{tabular}{|c|c|c|c|c|c|c|c|c|}
\hline \multirow{3}{*}{ Lags } & \multicolumn{4}{|c|}{ Developed } & \multicolumn{4}{|c|}{ Emerging } \\
\hline & \multicolumn{2}{|c|}{ without trend } & \multicolumn{2}{|c|}{ with trend } & \multicolumn{2}{|c|}{ without trend } & \multicolumn{2}{|c|}{ with trend } \\
\hline & pb & p-value & pb & p-value & pb & p-value & pb & p-value \\
\hline 0 & -6.406 & 0.000 & -5.740 & 0.000 & -6.477 & 0.000 & -5.453 & 0.000 \\
\hline 1 & -5.978 & 0.000 & -5.113 & 0.000 & -5.493 & 0.000 & -4.091 & 0.000 \\
\hline 2 & -5.299 & 0.000 & -4.469 & 0.000 & -3.972 & 0.000 & -2.846 & 0.000 \\
\hline 3 & -4.297 & 0.000 & -3.210 & 0.001 & -2.898 & 0.000 & -1.451 & 0.000 \\
\hline
\end{tabular}

For Pesaran (2007) the statistics Zt-bar and the corresponding $p$-value are reported.

The null hypothesis is that the series is non-stationary.

The deterministic elements and the lags are related to the Dickey Fuller regressions.

The routine "multipurt" from Markus Eberhardt was used, covering the routines "xtfisher" and "pescadf" written, respectively, by Scott Merryman and Piotr Lewandowski.

Results at $5 \%$ significance. 
Table A3 Tests of co-integration in panel:

pbfm and drgdp - Tests of Westerlund (2007) and Pedroni (1999)

Test of Westerlund, 2007 - Developed

\begin{tabular}{lrrrrrr}
\hline Statistics & value & z-value & p-value & \multicolumn{2}{|c}{ robust p-value* } \\
\hline Gt & -4.934 & -14.355 & 0,0000 & 0,0000 & 0,0000 \\
\hline $\mathrm{Ga}$ & -45.667 & -22.704 & 0,0000 & 0,0000 & 0,0000 \\
\hline $\mathrm{Pt}$ & -20.454 & -12.819 & 0,0000 & 0,0000 & 0,0000 \\
\hline $\mathrm{Pa}$ & -40.810 & -23.850 & 0,0000 & 0,0000 & 0,0000 \\
\hline
\end{tabular}

Test of Pedroni, 1999

\begin{tabular}{|c|c|c|c|c|c|}
\hline \multirow{2}{*}{ Statistics } & \multicolumn{2}{|c|}{ Developed } & \multicolumn{2}{|c|}{ Emerging } & \multirow{10}{*}{ 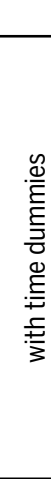 } \\
\hline & Panel & Group & Panel & Group & \\
\hline v & 5,50 & & 3,73 & & \\
\hline rho & $-28,45$ & $-23,48$ & $-22,70$ & $-17,32$ & \\
\hline$t$ & $-25,69$ & $-27,07$ & $-20,74$ & $-20,86$ & \\
\hline adf & $-23,95$ & $-24,62$ & $-20,16$ & $-20,05$ & \\
\hline $\mathrm{n}$ & \multicolumn{2}{|c|}{1290} & \multicolumn{2}{|c|}{801} & \\
\hline Variable & Beta & $\mathbf{t}$ & Beta & $\mathbf{t}$ & \\
\hline debtgdp & 0,0696 & 1,9180 & 0,0434 & 0,2307 & \\
\hline $\mathrm{n}$ & \multicolumn{2}{|c|}{1190} & \multicolumn{2}{|c|}{717} & \\
\hline Statistics & Panel & Group & Panel & Group & \multirow{9}{*}{ 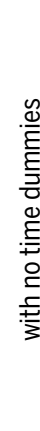 } \\
\hline v & 8,13 & & 7,63 & & \\
\hline rho & $-27,36$ & $-24,78$ & $-24,50$ & $-20,23$ & \\
\hline$t$ & $-17,73$ & $-20,60$ & $-15,34$ & $-16,63$ & \\
\hline adf & $-11,52$ & $-10,99$ & $-11,24$ & $-10,41$ & \\
\hline$n$ & \multicolumn{2}{|c|}{1290} & \multicolumn{2}{|c|}{801} & \\
\hline Variável & Beta & $\mathbf{t}$ & Beta & $\mathbf{t}$ & \\
\hline debtgdp & 0,1638 & $-27,35$ & 0,1046 & $-11,92$ & \\
\hline$n$ & 1230 & & 751 & & \\
\hline
\end{tabular}

Ho: there is no co-integration in both tests. In Westerlund, average lag and lead of, respectively, 2.35 and 1.05 , both selected by criterion AIC.

Robust $p$-value calculated with a bootstrap. In Pedroni, Beta obtained by method Pooled Mean Group (PMG). Where: "Pbfm" refers to Primary Balance of the Government and "drgdp" to the Growth Rate of the Real GDP. Results at $5 \%$ significance. 
Table A4 Test of cross-section dependence:

Primary balance of the government Test of Pesaran (2004)

\begin{tabular}{l|r|r|r|r}
\hline Variable & Test CD & p-value & corr & abs(corr) \\
\hline Developed & 30,10 & 0,000 & 0,273 & 0,316 \\
\hline Emerging & 9,29 & 0,000 & 0,135 & 0,192 \\
\hline
\end{tabular}

Ho: Cross-section independence.

Results at 5\% significance.

Table A5 Causalities between primary balance and GDP growth.

Kónya Test at $5 \%$ significance - jdd as control

\begin{tabular}{|c|c|c|c|c|}
\hline Causality & \multicolumn{2}{|c|}{ Coef. Sign } & Developed Countries & Emerging Countries \\
\hline \multirow{2}{*}{$\begin{array}{l}\text { Lag of the pri- } \\
\text { mary result for } \\
\text { GDP growth }(\varphi)\end{array}$} & \multicolumn{2}{|c|}{+} & - & Venezuela \\
\hline & \multicolumn{2}{|c|}{-} & - & \\
\hline \multirow{3}{*}{$\begin{array}{l}\text { Lag of the GDP } \\
\text { growth for pri- } \\
\text { mary result }(\beta)\end{array}$} & \multicolumn{2}{|c|}{+} & Alemanha & Filipinas e Tailândia \\
\hline & \multicolumn{2}{|c|}{-} & - & Brasil e Turquia \\
\hline & $\varphi$ & $\beta$ & & \\
\hline \multirow{4}{*}{ Bidirectional } & + & - & Irlanda & - \\
\hline & - & + & Dinamarca, Japão e Portugal & - \\
\hline & + & + & - & - \\
\hline & - & - & - & - \\
\hline None & \multicolumn{2}{|c|}{ NA } & Austrália & - \\
\hline
\end{tabular}

Causality Test for the Primary Balance in direction to the GDP Growth: $Y_{N, t}=\alpha+\Sigma \beta Y_{t-1}+\Sigma \phi X_{t-1}+\varepsilon$ and the GDP Growth in direction to the Primary Balance: $X_{N, t}=\alpha+\Sigma \beta Y_{t-1}+\Sigma \phi X_{t-1}+\varepsilon$

Data not available in either equations for Ecuador, El Salvador, India, Indonesia, Kenya, Malaysia, Nigeria, Peru, Singapore, Sri Lanka and Uruguay (emerging countries).

Data is not sufficient for: Austria, Belgium, Canada, Finland, Greece, Italy, Netherlands, New Zealand, Norway, Spain, Sweden and England (developed countries); and Bolivia, Colombia, Chile, Costa Rica, Ghana, Mexico and South Africa (emerging countries).

Where: * indicates results at $5 \%$ significance. 
Table A6 Robust standard-errors to the correlation and heteroscedasticity:

Impact of the primary balance in the GDP growth (with interest rate as a control variable)

\begin{tabular}{|c|c|c|c|c|c|c|c|c|c|c|}
\hline \multirow{2}{*}{ Panel } & \multirow{2}{*}{ Variable } & \multicolumn{3}{|c|}{ FGLS (2) } & \multicolumn{3}{|c|}{ FGLS (3) } & \multicolumn{3}{|c|}{ FGLS (4) } \\
\hline & & Coef. & Estat. z & $p>|z|$ & Coef. & Estat. z & $p>|z|$ & Coef. & Estat. z & $p>|z|$ \\
\hline \multirow{6}{*}{ 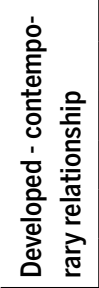 } & pbfm & 0,0934 & 5,08 & $0,000 *$ & 0,1275 & 5,14 & $0,000 *$ & 0,1104 & 4,16 & $0,000^{*}$ \\
\hline & jdd & $-0,0536$ & $-2,8$ & $0.005^{*}$ & $-0,0627$ & $-2,39$ & $0.017^{*}$ & $-0,0754$ & $-2,67$ & 0,008 \\
\hline & trend & $-0,0482$ & $-10,24$ & $0,000^{*}$ & $-0,0496$ & $-7,14$ & $0,000^{*}$ & $-0,0528$ & $-7,41$ & $0,000^{*}$ \\
\hline & constant & 4,9143 & 20,51 & $0,000^{*}$ & 5,0171 & 14,43 & $0,000 *$ & 5,1704 & 14,46 & $0,000^{*}$ \\
\hline & Wald chi2 & 127,61 & & & 77,05 & & & 71,06 & & \\
\hline & Prob>chi2 & 0,000 & & & 0,000 & & & 0,000 & & \\
\hline \multirow{6}{*}{ 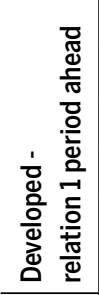 } & lagpbfm & 0,0052 & 0,28 & 0,778 & $-0,044$ & $-1,770$ & 0,076 & $-0,058$ & $-2,230$ & $0.026^{*}$ \\
\hline & jdd & $-0,0665$ & $-3,46$ & $0.001^{*}$ & $-0,086$ & $-3,280$ & $0.001^{*}$ & $-0,084$ & $-2,980$ & $0.003^{*}$ \\
\hline & trend & $-0,0471$ & $-9,87$ & $0,000^{*}$ & $-0,047$ & $-6,630$ & $0,000^{*}$ & $-0,050$ & $-7,030$ & $0,000^{*}$ \\
\hline & constant & 5,0611 & 21,12 & $0,000^{*}$ & 5,230 & 14,970 & $0,000^{*}$ & 5,339 & 15,290 & $0,000^{*}$ \\
\hline & Wald chi2 & 103,39 & & & 54,730 & & & 62,770 & & \\
\hline & & 0,000 & & & 0,000 & & & 0,000 & & \\
\hline \multirow{6}{*}{ 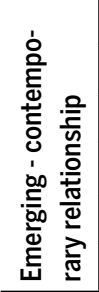 } & pbfm & 0,1866 & 3,75 & $0,000^{*}$ & 0,1910 & 3,51 & $0,000^{*}$ & 0,1272 & 2,14 & $0.032^{*}$ \\
\hline & jdd & $-0,0006$ & $-2,87$ & $0.004^{*}$ & $-0,0005$ & $-2,17$ & $0.03^{*}$ & $-0,0005$ & $-2,99$ & $0.003^{*}$ \\
\hline & trend & $-0,0271$ & $-2,58$ & $0.01^{*}$ & $-0,0254$ & $-1,83$ & 0,068 & $-0,0113$ & $-0,62$ & 0,538 \\
\hline & constant & 4,7973 & 10,10 & $0,000^{*}$ & 4,736 & 7,49 & $0,000^{*}$ & 4,1994 & 4,87 & $0,000^{*}$ \\
\hline & Wald chi2 & 23,00 & & & 16,97 & & & 13,00 & & \\
\hline & Prob>chi2 & 0,000 & & & 0,001 & & & 0,005 & & \\
\hline \multirow{6}{*}{ 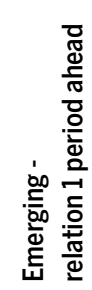 } & lagpbfm & 0,1562 & 3,21 & $0.001^{*}$ & 0,1181 & 2,17 & $0.03^{*}$ & 0,1196 & 1,95 & 0,051 \\
\hline & jdd & $-0,0005$ & $-2,64$ & $0.008^{*}$ & $-0,0004$ & $-1,89$ & 0,058 & $-0,0005$ & $-2,85$ & $0.004^{*}$ \\
\hline & trend & $-0,0262$ & $-2,44$ & $0.015^{*}$ & $-0,0230$ & $-1,63$ & 0,104 & $-0,0127$ & $-0,68$ & 0,496 \\
\hline & constant & 4,7604 & 9,82 & $0,000 *$ & 4,6010 & 7,24 & $0,000^{*}$ & 4,2519 & 4,89 & $0,000^{*}$ \\
\hline & Wald chi2 & 19,24 & & & 9,65 & & & 12,33 & & \\
\hline & Prob $>$ chi 2 & $0,000^{*}$ & & & $0.0218^{*}$ & & & 0,063 & & \\
\hline
\end{tabular}

The estimates use interest rate as a control variable.

FGLS (2) with robust trend and errors to heteroscedasticity between the panels.

FGLS (3) with robust trend and errors to heteroscedasticity and autocorrelation (AR 1).

FGLS (4) with robust trend and errors to autocorrelation per panel (PSAR1).

The estimates for (20) developed countries have 819 observations and for (13) emerging countries, 511 observations.

Where "pbfm" refers to the Government Primary Balance; "jdd" to the series of interest rate obtained, as Moreira and Rocha (2009), from consolidation of the series of interest rates of discount and deposit; "tend" and * indicates results at $5 \%$ significance. 